\title{
The Effect Of Osha, Work Environment And Work Discipline On Employee Satisfaction And Employee Performance
}

\author{
Tri Andjarwati
}

Beni Agus Setiono

Kunto Eko Susilo

Endah Budiarti

Enni Sustiyatik

Abdul Kadir Audah

Agnes Filindawati Winarno

\begin{abstract}
This study aims to analyze the effect of Occupational Safety and Health (OSHA), work environment and work discipline on job satisfaction and employee performance. The method used in this study is a survey conducted on the employees of PT. Maspion I Maxim Division of the Spray Coating Department. The sampling method uses saturated sampling, by taking the entire population of 70 employees to be respondents. The data used in this study are primary data. Data analysis and hypothesis testing in this study used Goodness of fit analysis in the Partial Least Square model. The results showed that the work environment and work discipline variables had a significant effect on employee performance while OSHA had no significant effect on employee performance. OSHA implementation and work discipline have a significant effect on job satisfaction. The environment has no significant effect on employee job satisfaction.
\end{abstract}

Keywords: OSHA, work environment, work discipline, job satisfaction, employee performance

\section{INTRODUCTION}

The organization needs human resources as a system manager to achieve its goals, so that the system certainly runs in its management must pay attention to several important aspects relating to employee safety One of these important aspects can be elaborated through the implementation of an occupational safety management system.

Work safety is a safe condition from suffering, damage or loss at work. Occupational health is a condition that is free from physical, mental, emotional or pain disorders caused by the work environment. The causes of work accidents are caused by humans and the environment. The human factor is related to unsafe actions related to rules and conditions of work. Work accidents also occur due to unsafe working environment conditions related to work equipment.

Performance is the result of work achieved by someone in quality and quantity, with the implementation of the OSHA program will create a sense of security and comfort for employees at work, thus encouraging employee performance. The work environment is everything that is 
around the employee at work both physically and non-physically and affects employees while working. If the work environment is conducive then the employee feels safe and comfortable. With a supportive work environment, a pleasant work atmosphere, harmonious relations with colleagues, the availability of adequate work facilities and guaranteed security can support the work process and improve performance.

Discipline is a way to raise awareness for workers to carry out the tasks that have been given. Discipline is the key to a company's success in achieving its goals, the higher the discipline of an employee, the greater the work performance that can be generated.

Job satisfaction leads to high performance, the most fundamental thing is the effect of job satisfaction on the organization that will affect employee performance. The purpose of this study is to prove and analyze the effect of OSHA, work environment and work discipline on job satisfaction and employee performance.

\section{LITERATURE REVIEW}

Human Resources is an aspect that is needed to achieve company goals because employees are the main aspects of the company by using management principles, so employees work regularly. Human resource management directly involves decisions and employee performance directly in doing work. According to experts in human resource management, among others, as follows the process of human empowerment as human labor, so that all of its physical and psychological potentials function optimally to achieve this goal, stated by Ardana (2012: 5).

Hasibuan (2015: 279) revealed that human resource management is the science and art of regulating the relationship and role of the workforce to be effective and efficient in helping the realization of company, employee and community goals.

OSHA is one of the factors that influence employee performance because it is important to keep employees feeling safe and protected while at work as well as carrying out procedures that are set by the company. Work accidents cause company performance disrupted because employees are an important factor for the company. According to occupational safety and health experts are conditions that are safe or safe from suffering, damage or loss at work stated by Mangkunegara (2011: 161). This shows that occupational safety and health are very important because they will harm employees and the company in the event of an accident or damage to the machine that will disrupt the production of the company itself.

Meanwhile, according to Ardana (2012) Occupational Safety and Health is a protective effort aimed at ensuring that workers and other people in the workplace are always safe and healthy so that every source of production can be used safely and efficiently. In order to always maintain safety at work and health so that the work carried out can be run optimally.

The environment at work is an aspect that directly touches the employee because every day the employee occupies the work environment to carry out the work producing the output expected by the company. According to work environment experts, Wahyuningsih (2014) stated that employees really expect conducive and supportive working environment conditions in each process of carrying out their work, but in reality there are still many shortcomings and even limited availability of supporting facilities and infrastructure. Employees will be comfortable when working when the environment becomes conducive and orderly. And also expressed by Sunyoto (2015: 38) work environment is a very important component when employees carry out work activities. 
In doing a job, it requires discipline to do work in order to be efficient and effective. And the work needs to have rules that govern every job so that employees who work can obey the rules in the company to avoid undesirable things such as discipline in the company. As halya revealed by Sutrisno (2009: 86) discipline shows a condition or attitude of respect that exists in employees against if the rules or are often violated, then employees have poor work discipline. And another definition of work discipline from Anoraga (2006: 80) is an attitude, an act to always obey order.

Job satisfaction is an emotional form of employees when they feel the work they are doing well or not going well. In terms of doing work the employees always have their own views about the work and the work environment of employees whether in accordance with expectations and can arouse employee morale itself. According to Koesmono (2005) stated that job satisfaction is an assessment, feelings or attitudes of a person or employee towards their work and is related to the work environment, type of work, compensation, relationships between colleagues, social relations at work and so on.

Employee performance is an aspect that needs to be considered by the company because of various things that affect employee performance. A good company is a company that pays attention to every detail of work done by employees so that future performance increases. Understanding of employee performance according to Robbins (2008), performance is the optimal achievement in accordance with the potential of an employee is something that always concerns the leaders of the organization. Mangkunegara (2015) the term performance comes from the word job performance or actual performance.

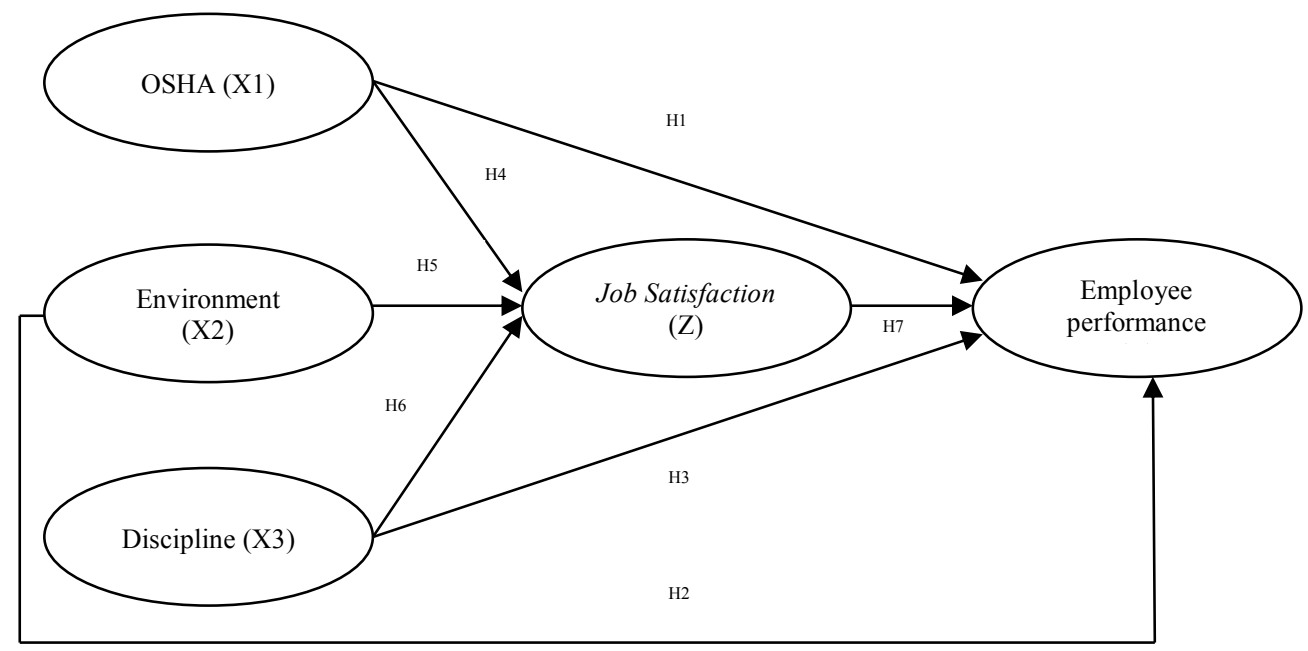

Figure 1. Conceptual framework

Hypothesis: OSHA, work environment and work discipline have a significant effect on job satisfaction and employee performance.

\section{METHODOLOGY}

Based on the influence of its relationship with other variables the variables in this study are grouped into exogenous constructs, in this study called independent variables include OSHA, work environment and work discipline. Endogenous constructs are called dependent variables, namely employee performance and intervening variables, namely employee satisfaction. The sampling method uses saturated sampling, by taking the entire population of 70 employees to be respondents. 


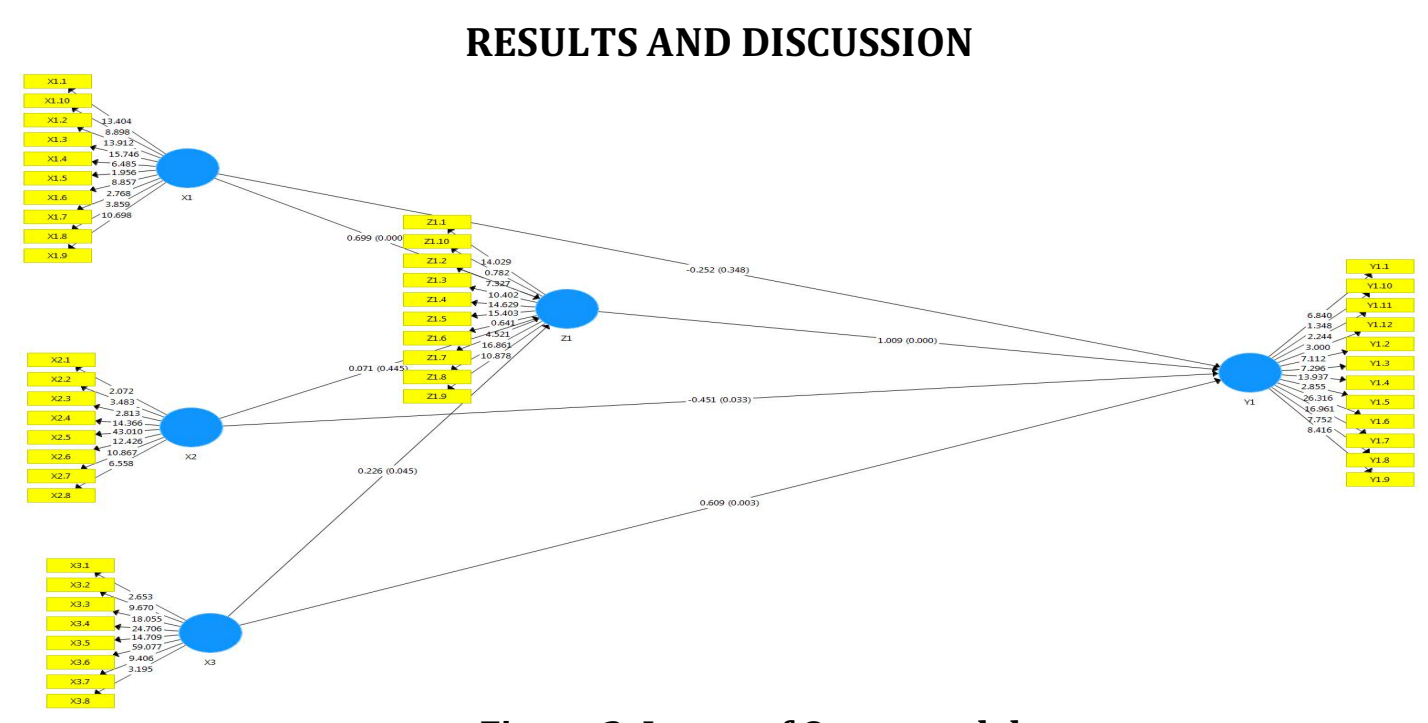

Figure 2. Image of Outer model

In the outer analysis this model is used to measure convergent validity, discriminant validity and composite reliability. Figure 1 is a model developed in this study.

\section{Convergent Validity}

This study uses an outer loading value where an indicator is said to meet when the outer loading value is $>0.4$. The results for outer loading are indicators of occupational safety and health variables $\left(\mathrm{X}_{1}\right)$ including personal protective equipment, safe work space, use of work equipment, healthy work space, lighting in the work space; work environment variable indicators $\left(\mathrm{X}_{2}\right)$, namely workplace buildings, adequate work equipment, facilities, transportation facilities; indicator of work discipline variable $\left(\mathrm{X}_{3}\right)$, which is obeying the rules of time, obeying company regulations, obeying the rules of behavior at work, obeying other company regulations; indicators of job satisfaction variables $\left(\mathrm{Z}_{1}\right)$, which are mentally challenging jobs, supportive working conditions, appropriate salary or wages, personality conformity with work, supportive workmates; Employee performance variable indicators $\left(\mathrm{Y}_{1}\right)$ namely quality, quantity, timeliness, effectiveness, independence, work commitment and overall indicators of each variable indicate that the value is more than 0.4 . So this shows that all indicators that compose each variable used in this study have fulfilled convergent validity so that all indicators can be used for further analysis.

\section{Discriminant Validity}

In this study an indicator is said to be valid or fulfilling if the cross loading indicator value for the construct is the largest compared to the others. Based on the test results it can be said that the indicators used in this study already have good discriminant validity in preparing their respective variables.

\section{Composite Reliability}

This analysis examines the value of indicator reliability in a construct. A construct or variable is said to fulfill it if it has a composite reliability value $>0.7$. In this model, each variable meets the composite reliability. The test results show the value of composite reliability for variable promotions, compensation, job stress, job satisfaction and overall employee performance are all more than 0.7. This shows that in the measurement model of this study each variable has met the composite reliability.

\section{Inner model}

In evaluating the inner model, it will measure the R-square value and the kasuality test. Figure 2 is a picture of the structural model developed in this study. 


\section{R-Square}

In this study Goodness of fit analysis on the PLS model can be known from the Q2 value. Q2 value has the same meaning as $\mathrm{R}^{2}$ in the regression analysis. The higher $\mathrm{R}^{2}$, the model can be said to be more fit with the data. Based on data processing in PLS, getting this structural model assessment is good. This is because the R-Square value obtained by job satisfaction is $96.2 \%$ and for employee performance is $88.0 \%$ where for the results of these variables the higher the better because of the influence of job satisfaction on the independent variable the strong influence as well as employee performance which also has a strong influence on the independent variables, namely occupational safety and health, work environment and work discipline.

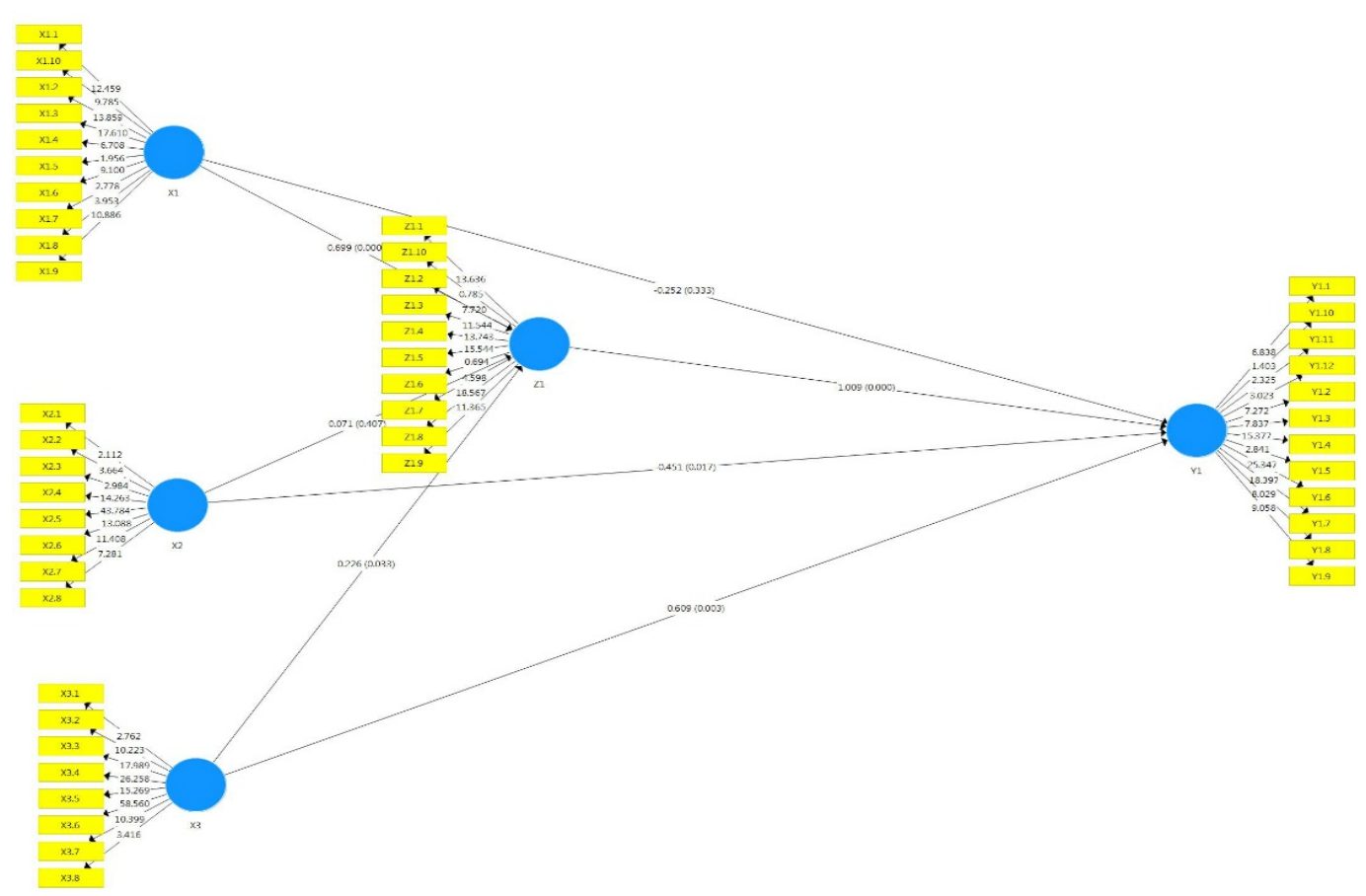

Figure 3. Image: Inner Model

\section{Hypothesis testing}

Used to test the hypothesis of this study the hypothesis can be accepted if the value of t-count (t-statistic) is greater than $\mathrm{t}$-table at an error rate of $5 \%$ which is equal to 1.96 .

Table 1. The table of path coefficient values and the results of the calculated $t$-value in the inner model

\begin{tabular}{|l|c|c|c|c|c|}
\hline \multicolumn{1}{|c|}{ Variable } & $\begin{array}{c}\text { Original } \\
\text { Sample }\end{array}$ & $\begin{array}{c}\text { Standard } \\
\text { Deviation }\end{array}$ & T Statistics & P Value & Information \\
\hline OSHA $\rightarrow$ Performance & -0.252 & 0.260 & 0.969 & 0.333 & Not Significant \\
\hline $\begin{array}{l}\text { Environment } \rightarrow \\
\text { Performance }\end{array}$ & -0.451 & 0.189 & 2.385 & 0.017 & Significant \\
\hline $\begin{array}{l}\text { Discipline } \rightarrow \\
\text { Performance }\end{array}$ & 0.609 & 0.202 & 3.010 & 0.003 & Significant \\
\hline OSHA $\rightarrow$ Satisfaction & 0.699 & 0.072 & 9.730 & 0.000 & Significant \\
\hline $\begin{array}{l}\text { Environment } \rightarrow \\
\text { Satisfaction }\end{array}$ & 0.071 & 0.085 & 0.829 & 0.407 & Not Significant \\
\hline $\begin{array}{l}\text { Discipline } \rightarrow \\
\text { Satisfaction }\end{array}$ & 0.226 & 0.106 & 2.138 & 0.033 & Significant \\
\hline $\begin{array}{l}\text { Satisfaction } \rightarrow \\
\text { Performance }\end{array}$ & 1.009 & 0.239 & 4.230 & 0.000 & Significant \\
\hline
\end{tabular}


The results showed that OSHA and work discipline had a significant effect on employee job satisfaction. The higher the level of OSHA and work discipline, job satisfaction of employees of PT. Maspion I of the Maxim Division of the Spray Coating Department will also increase. The environment does not have a significant effect on employee job satisfaction. The results of this study support the research of Wibowo (2016) Dotulong (2015) which states the work environment influences job satisfaction.

The results of testing OSHA variables, work environment and work discipline on employee performance support the research of Firmanzah, Hamid and Djudi (2017) OSHA has no significant effect on employee performance. Sofyan (2013) The work environment has a significant effect on employee performance. Syahfrina (2017) work discipline has a significant effect on employee performance.

The results of testing between job satisfaction variables on employee performance can be concluded that there is a significant influence on employee performance. The greater job satisfaction felt by employees, the more the performance of employees of PT. Maspion The results of research that support the results conducted by Nur (2013) explain that job satisfaction has a significant effect on employee performance, where the higher level of job satisfaction will bring a positive influence in improving employee performance.

Job satisfaction testing is an OSH intervening variable, work environment, and work discipline on employee performance. The results of this study are supported by research conducted by Wibowo (2016) which suggests that job satisfaction is an intervening variable among the effects of OSHA on employee performance. Another study conducted by Safrina (2017) showed that job satisfaction is an intervening variable between work discipline and employee performance. Hanafi (2017) state that job satisfaction is a perfect mediation between work environment and employee performance.

\section{CONCLUSION}

Job satisfaction in companies is influenced by OSHA and high work discipline, while for the work environment itself does not affect job satisfaction. To improve employee performance, the company is influenced by the work environment and work discipline while applying OSHA does not affect employee performance.

\section{References}

Ardana, I Komang 2012 Human Resource Management. Yogyakarta: Graha knowledge

Diana Khairani Sofyan 2013. The Effect of Work Environment on Employee Work Performance Journal Vol 2 No. 1

Firmanzah Afrizal, Djamhur Hamid, Mochamad Djudi 2017 Effect of K3 on Employee Performance Business Administration Journal Vol 42 No 2

Hanafi Dwilaksono Bayu, Corry Yohana. 2017. Effect of Motivation and Work Environment on Employee Performance with Job Satisfaction as Mediation Variables Journal of Economic and Business Education Vol 5 No 1

Hasibuan, Malayu. 2015. Human Resources Management, Publisher: PT. Bumi Aksara, Jakarta.

Lumentut D.S Mauritz. Lucky O.H Dotulong. 2015. The Effect of Motivation, Discipline, and Work Environment on Employee Job Satisfaction Vol. EMBA Journal Vol.3 No.1

Mangkunegara, Anwar Prabu 2015 Corporate Human Resource Management. Bandung: Teen Rosdakarya.

Robbins, S. 2008. Organizational Behavior, Jakarta: Prenhallindo

Safrina Emi. 2017. The Effect of Discipline, Compensation and Communication on Employee Performance with Job Satisfaction as Intervening Variables in the Bireuen Regency Gas Station Journal of Economics and Business, Vol. 18 No. 2

Sunyoto, Danang 2015 Management and Development of Human Resources Yogyakarta: CAPS 
Sutrisno, Edi 2016 Human Resource Management Jakarta: Prenadamedia Group

Wibowo Endro. Hardi Utomo. 2016. The Effect of K3 on Performance with Job Satisfaction as an intervening variable Among Makarti Vol. 9 No. 17

Yunus Alamsyah, Ahmad Alim Bachri 2013. The Effect of Work Discipline, Motivation, Leadership on Employee Job Satisfaction Management Insights Journal, Vol. 1, No 2 